\title{
Crosstalk of carcinoembryonic antigen and transforming growth factor- $\beta$ via their receptors: comparing human and canine cancer
}

\author{
Erika Jensen-Jarolim ${ }^{1} \cdot$ Judit Fazekas $^{1} \cdot$ Josef Singer $^{1} \cdot$ Gerlinde Hofstetter $^{1}$ • \\ Kumiko Oida $^{2} \cdot$ Hiroshi Matsuda $^{2} \cdot$ Akane Tanaka $^{2}$
}

Received: 12 December 2014 / Accepted: 19 March 2015 / Published online: 2 April 2015

(c) The Author(s) 2015. This article is published with open access at Springerlink.com

\begin{abstract}
There is accumulating evidence that the transforming growth factor beta (TGF- $\beta$ ) and nuclear factor kappa-B (NFкB) pathways are tightly connected and play a key role in malignant transformation in cancer. Immune infiltration by regulatory $\mathrm{T}$ - and B-lymphocytes (Tregs, Bregs) has recently gained increased attention for being an important source of TGF- $\beta$. There is a plethora of studies examining the pro-tumorigenic functions of carcinoembryonic antigen (CEA), but its receptor CEAR is far less studied. So far, there is a single connecting report that TGF- $\beta$ also may signal through CEAR. The crosstalk between cancer tissues is further complicated by the expression of CEAR and TGF- $\beta$ receptors in stromal cells, and implications of TGF- $\beta$ in epithelial-mesenchymal transition. Furthermore, tumor-infiltrating Tregs and Bregs may directly instruct cancer cells by secreting TGF- $\beta$ binding to their CEAR. Therefore, both TGF- $\beta$ and CEA may act synergistically in breast cancer and cause disease progression, and $\mathrm{NF \kappa B}$ could be a common crossing point between their signaling. CEAR, TGF- $\beta 1-3$, TGF- $\beta-R$ types I-III and NFKB class I and II molecules have an outstanding human-canine sequence identity, and only a canine CEA homolog has not yet been identified. For these reasons, the
\end{abstract}

Erika Jensen-Jarolim

erika.jensen-jarolim@meduniwien.ac.at

1 Department of Comparative Medicine, Comparative Immunology and Oncology, Messerli Research Institute of the University of Veterinary Medicine Vienna, c/o Institute of Pathophysiology and Allergy Research, AKH 4Q, Medical University Vienna and University Vienna, Waehringer Guertel 18-20, 1090 Vienna, Austria

2 Comparative Animal Medicine, Division of Animal Life Science, Institute of Agriculture, Tokyo University of Agriculture and Technology, Fuchu, Tokyo, Japan dog may be a valid translational model patient for investigating the crosstalk of the interconnected CEA and TGF- $\beta$ networks.

Keywords Carcinoembryonic antigen (CEA) - CEAreceptor (CEAR) - Transforming growth factor beta (TGF$\beta) \cdot$ Cancer immunology $\cdot$ Regulatory $\cdot$ Nuclear factor kappa-B (NFkB)

$\begin{array}{ll}\text { Abbreviations } \\ \text { AAV } & \text { Adeno-associated virus } \\ \text { Akt } & \text { Protein kinase B } \\ \text { Breg } & \text { Regulatory B-lymphocyte } \\ \text { CEA } & \text { Carcinoembryonic antigen (CEACAM5) } \\ \text { CEACAM } & \text { Carcinoembryonic antigen-related cell } \\ & \text { adhesion molecule } \\ \text { CEAR } & \text { Carcinoembryonic antigen receptor } \\ \text { CEARL } & \text { Carcinoembryonic antigen receptor, long } \\ & \text { isoform } \\ \text { CEARS } & \text { Carcinoembryonic antigen receptor, short } \\ & \text { isoform } \\ \text { EGF } & \text { Epidermal growth factor } \\ \text { EGFR } & \text { Epidermal growth factor receptor (ErbB1) } \\ \text { EMT } & \text { Epithelial-to-mesenchymal transition } \\ \text { FGF } & \text { Fibroblast growth factor } \\ \text { HER-2 } & \text { Human epidermal growth factor receptor } 2 \\ \text { HGF } & \text { (ErbB2) } \\ \text { hnRNP M4 } & \text { Hepatocyte growth factor } \\ \text { IGFs } & \text { (CEAR) } \\ \text { IKK } & \text { Insulin-like growth factors } \\ \text { IKKb } & \text { Inhibitor of nuclear factor kappa-B kinase } \\ \text { subunit beta } & \text { Inhibitor of kappa-B } \\ & \end{array}$




\begin{tabular}{|c|c|}
\hline IкB $\alpha$ & Inhibitor of kappa-B subunit alpha \\
\hline MDCK & Madin-Darby canine kidney cell line \\
\hline MEK & Mitogen-activated protein kinase kinase \\
\hline NFKB & Nuclear factor kappa-B \\
\hline PDGF & Platelet-derived growth factor \\
\hline RelA & $\begin{array}{l}\text { v-Rel avian reticuloendotheliosis viral } \\
\text { oncogene homolog A }\end{array}$ \\
\hline SMAD & SMA and MAD homolog \\
\hline TAB1 & TAK1-binding protein 1 \\
\hline TAK1 & $\begin{array}{l}\text { Transforming growth factor-activated } \\
\text { kinase-1 }\end{array}$ \\
\hline TGF- $\beta$ & Transforming growth factor beta \\
\hline TGF- $\beta-R$ & Transforming growth factor beta receptor \\
\hline Treg & Regulatory T-lymphocyte \\
\hline
\end{tabular}

\section{Introduction}

The strategy of comparative oncology is to find homologous molecules, homologous signaling cascades and homologous immune mechanisms to cure cancer in both humans and pets according to the "One Health" principle [1]. Similar to humans, dogs spontaneously develop malignancies with comparable incidence and prevalence and hence represent a natural model for human cancer. For instance, a Swedish study on 80,000 insured female dogs reported that, dependent on higher age and breed, up to $13 \%$ of female dogs had at least one mammary tumor, with an overall-case fatality of $6 \%$ [2]. In humans, females in more highly developed areas have a cumulative risk of $7.1 \%$ of developing mammary cancer by the age of 75 , with a mortality rate of $1.7 \%$ [3]. Mammary carcinoma, among others, is thus a burden in both human and veterinary medicines.
The rationale for favouring this tumor entity for comparative studies derives from the fact that it is wise to have access to primary lesions for monitoring tumor progression by caliper measurements. This facilitates the clinical investigations and also takes into consideration that only few centers have access to imaging facilities. Often more than one mamilla are affected in canine cancer patients and may be compared side by side.

It can further be expected that results from comparative oncology studies, investigating naturally occurring cancers due to distinct risk factors in distinct breeds, have a higher translational potential than studies with genetically highly homologous mouse strains [4]. For example, the epidermal growth factor receptor (EGFR) family members EGFR (ErbB1) and human epidermal growth factor receptor 2 (HER-2 (ErbB2)) are molecules of outstanding homology between humans and dogs, and targeting of these molecules results in the same effects on signaling and cancer biology in both species [5, 6].

A more intricate situation was observed for the carcinoembryonic antigen [CEA, also termed carcinoembryonic antigen-related cell adhesion molecule 5 (CEACAM5)], which represents a classical soluble as well as membraneexpressed tumor marker in human clinical oncology. Serum levels of soluble human CEA correlate with disease progression [7], and its assessment is recommended in monitoring the treatment course of colorectal cancer in combination with other prognostic markers $[8,9]$. However, CEA molecules are structurally and evolutionarily diverse between humans and canines $[10,11]$. A direct CEA homolog in dogs has not yet been defined and represents "a missing link" (Table 1). In contrast, overexpression of CEA in humans has been known for over 20 years to play an important role in metastasis and cell motility [12] by acting as a ligand for E- and L-selectins

Table 1 Interspecies amino acid sequence comparisons

\begin{tabular}{|c|c|c|c|c|}
\hline Molecule & Human & Canine & Sequence identity $(\%)$ & Sequence similarity $(\%)$ \\
\hline CEAR & HNRPM_HUMAN & XP_005633012.1 & 99.3 & 99.5 \\
\hline CEA (CEACAM5) & CEAM5_HUMAN & n.d. [20] & - & - \\
\hline TGF- $\beta$-RI & TGFR1_HUMAN & F1PS63_CANFA & 91.8 & 92.2 \\
\hline TGF- $\beta$-RII & TGFR2_HUMAN & F1PNA9_CANFA & 87.4 & 90.3 \\
\hline TGF- $\beta$-RIII & TGBR3_HUMAN & F1PIG0_CANFA & 88.6 & 93.0 \\
\hline TGF- $\beta 1$ & TGFB1_HUMAN & TGFB1-CANFA & 94.1 & 96.7 \\
\hline TGF- $\beta 2$ & TGFB2_HUMAN & F1PKH0_CANFA & 99.5 & 99.8 \\
\hline TGF- $\beta 3$ & TGFB3_HUMAN & F1PR85_CANFA & 88.4 & 89.5 \\
\hline NFאB1 & NFкB1_HUMAN & NFKB1_CANFA & 91.0 & 94.2 \\
\hline NFkB2 & NFкB2_HUMAN & E2RLL2_CANFA & 92.3 & 94.9 \\
\hline RelA & TF65_HUMAN & F1PCU1_CANFA & 91.2 & 93.5 \\
\hline
\end{tabular}

Sequences were from UniProt (http://www.uniprot.org/uniprot/) and from the National Center for Biotechnology Information (NCBI) (http:// www.ncbi.nlm.nih.gov/protein). Sequences were aligned using a Needleman-Wunsch algorithm (http://www.ebi.ac.uk/Tools/psa/) with a BLOSUM 62 matrix; gap penalty and end penalty were defined as 10.0 and 0.5 , respectively 
[13] and might have a signaling function probably by interacting with the Wnt pathway [14]. Furthermore, vaccination with an adeno-associated virus (AAV)-CEA vector combined with Toll-like receptor-9 or Toll-like receptor-7 agonists in wild-type mice resulted in enhanced Th1-mediated immunity and protection from challenge with MC38 colon tumor cells expressing CEA, whereas the same CEA vaccines in CEA transgenic animals promoted tumor growth due to tolerance phenomena elicited by dendritic and myeloid cells [15]. Some CEA family members such as CEACAM6 may adhere to and inhibit tumor-infiltrating cytotoxic $\mathrm{T}$ cells [16]. CEACAM1, CEACAM5 and CEACAM6 may be released from epithelial tumors in microvesicles, whereas tumor endothelia only contain CEACAM1 which has a receptor function for other CEACAMs, influences $\mathrm{T}$ cell behavior [17] and regulates the tumor matrix and microvascularization [18]. Hence, CEA may affect the tumor and its stroma at the same time [19].

\section{CEAR binds TGF $-\beta$, a cytokine involved in tolerance induction toward malignant tissue}

The scientific history of the carcinoembryonic antigen receptor (CEAR) is much more recent. Interestingly, CEAR showed an outstanding sequence identity of $99 \%$ between the human and canine species [20] (Table 1). The great CEA-receptor homology of humans and dogs on the one hand and the lack of a precise canine CEA equivalent on the other hand are discrepancies and indicate that there could be an alternative ligand. The CEAR was originally described in Kupffer cells and identified as the heterogeneous nuclear ribonucleoprotein M4 (hnRNP M4) [21]. Regarding oncology, it was later also found on colon cancer cells [22]. Moreover, its expression was subsequently also detected in mice in the entire gastrointestinal tract including liver and pancreas [23]. CEAR expression has been connected to inflammation in the liver [24]. In Kupffer cells, a full-length hnRNP M4 (CEARL) and a truncated form (CEARS), generated by alternative splicing, were described [14]. The minimal structural element of human CEACAM5 interacting with hnRNP M4/CEAR was reduced to a peptide of eight amino acids [25].

Surprisingly, a recent study has shown that CEA not only signals via its specific receptor, CEAR, but can also bind to the receptor of the important immunomodulatory cytokine transforming growth factor beta (TGF- $\beta$, Fig. 1) [26].

\section{TGF- $\beta$ sources and its function in the tumor}

Three high-affinity membrane-bound receptors for TGF- $\beta$ are known so far: type I, type II and type III. The classical

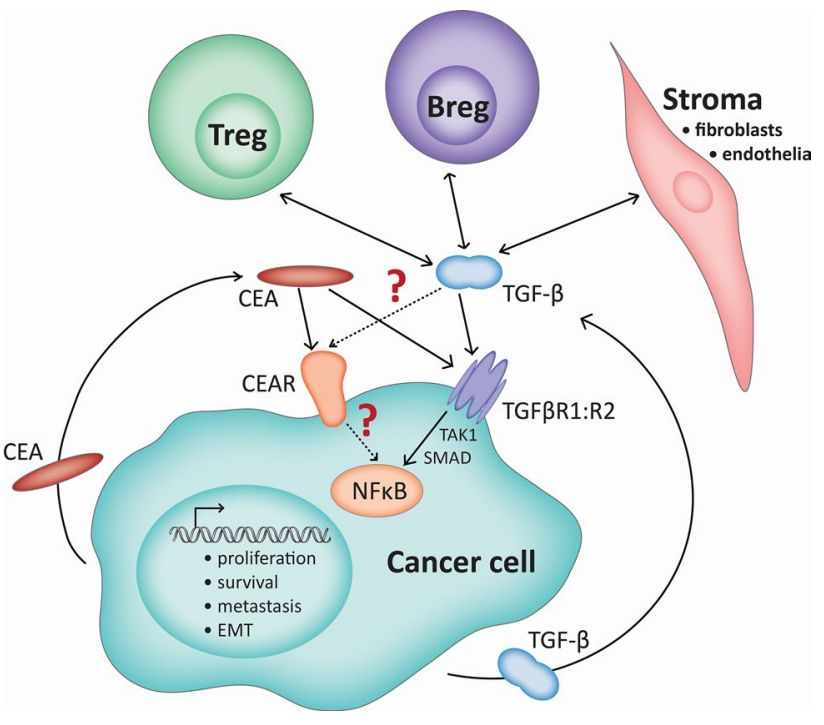

Fig. 1 Interconnected networks of CEA and TGF- $\beta$ signaling in cancer. The cancer cell is an autocrine source of CEA as well as of TGF- $\beta$ which bind to their specific receptors, CEAR or TGF- $\beta$ RI:RII, respectively; the latter signaling via the NFKB pathway. Recently, it has been recognized that CEA also signals via TGF- $\beta-R$ and initiates the same biological effects [26]. Additionally, Tregs and Bregs, as well as stroma cells, participate in this network by secreting TGF- $\beta$. It remains open whether the reverse is the case, and TGF- $\beta$ may also interfere with the CEAR pathway, which is much less defined

TGF- $\beta$ signaling, however, occurs via the heterotetrameric complex of 2 TGF- $\beta$-receptor (TGF- $\beta$-R) type I and 2 TGF- $\beta$-receptor type II transmembrane receptors with serine/threonine kinase activity [27-29]. In the tumor microenvironment, TGF- $\beta$ is most typically derived from human and canine Foxp $3^{+}$regulatory $\mathrm{T}$ cells (Tregs). It is well known that Tregs can thereby critically dampen antitumor immunity and tolerize cytotoxic $\mathrm{T}$ cells [30-34]. More recently, intratumoral regulatory B cells (Bregs) have gained attention in human oncology [35, 36]. According to Olkhanud et al. [37], tumor-evoked Bregs should phenotypically resemble activated mature $\mathrm{B} 2$ cells $\left(\mathrm{CD} 19^{+}\right.$ $\mathrm{CD} 25^{\mathrm{hi}} \mathrm{CD}^{\mathrm{hi}}{ }^{\mathrm{hi}}$. Lindner et al. [36] reported that intratumoral Bregs also express granzyme-B (stimulated by IL-21 from Tregs) and a signature of $\mathrm{CD} 19^{+} \mathrm{CD} 38^{+} \mathrm{CD} 1 \mathrm{~d}^{+} \mathrm{IgM}$ ${ }^{+} \mathrm{CD} 147^{+}$, as well as including IL-10, CD25 and indoleamine-2,3-dioxygenase. This population seems interesting as a source of TGF- $\beta$ and for their capacity to suppress intratumoral $\mathrm{CD}^{+}$and $\mathrm{CD} 4^{+}$effector $\mathrm{T}$ cells. Bregs can even convert naïve $\mathrm{CD} 4{ }^{+} \mathrm{CD} 25^{-} \mathrm{T}$ cells to Foxp $3^{+}$Tregs [37]. TGF- $\beta$, however, may also be derived from tumor stroma cells [19, 38], where it shapes the microenvironment by interacting with growth factors (epidermal growth factor (EGF), platelet-derived growth factor (PDGF), fibroblast growth factor (FGF), hepatocyte growth factor (HGF), insulin-like growth factor (IGF) [39]), cytokines or 
chemokines, crosstalking to fibroblasts [40] and supporting the enrichment of endothelial cells, which again shape the extracellular matrix [41]. TGF- $\beta$ promotes the loss of epithelial markers such as E-cadherin and the accumulation of the mesenchymal marker vimentin in the process of epithelial-mesenchymal transition (EMT) [42]. Importantly, in this case tumor stem cells themselves show an enrichment of mesenchymal markers and are a source of TGF- $\beta$. Most studies on EMT are done in mouse or human cancer models [43], but there are reports that EMT transition can be achieved by TGF- $\beta$ in (normal) Madin-Darby canine kidney (MDCK) cells [44].

Physiologically, TGF- $\beta$ acts as a tumor suppressor, negatively regulating cellular proliferation, but this is changed in the cancer microenvironment toward a tumor promoter function, where it mediates proliferation, migration, invasion, EMT and metastasis, associated with high miR-181a expression, and altogether termed the TGF- $\beta$-paradox [45]. In this context, it is important to note that canines are much closer to the human species than murine animal models. The appearance of Tregs also negatively correlates with prognosis in dog cancer patients [46].

For instance, naive $\mathrm{CD} 4^{+} \mathrm{CD} 25^{-}$Foxp $3^{-} \mathrm{T}$ cells can be converted to Foxp $3^{+}$Tregs when adoptively transferred into $\mathrm{Rag}^{-/-}$mice only in the presence of TGF- $\beta$-positive tumors [47]. Thus, the intratumoral milieu amplifies the cellular sources for even more immunosuppressive cytokines. It has been recently shown that elevated levels of TGF- $\beta$ and IL- 6 in the tumor microenvironment support Th17 cells and that the resulting inflammation was supporting the clinical development and progression of gastric cancer [48]. Although Li et al. have shown that CEA binds to TGF- $\beta-R$ [26], it has not yet been investigated whether the reverse is true, and TGF- $\beta$ (besides acting via its own TGF$\beta$-R) may crosstalk via CEAR, thereby imitating the tumorprogressive properties of CEA. CEA modulates effectortarget interaction by binding to lymphocytes [49]. Only CEACAM1 expression was previously described in T cells [50], whereas the expression of CEACAM5 on T cells was excluded. Regarding this, we are not aware of investigations on the expression of CEAR on T- or B-lymphocytes.

\section{TGF- $\beta$ signaling}

In contrast to CEAR, the cellular signaling function of which has to the best of our knowledge not yet been reported, the signaling cascade for the TGF- $\beta-R$ is well known. The nuclear factor kappa-B $(\mathrm{NF} \kappa \mathrm{B})$ is a key master regulator in growth and survival $[51,52]$. In normal cells, TGF- $\beta$ leads to growth inhibition; in short: TGF- $\beta$ binds to TGF- $\beta$-RII, activating TGF- $\beta-$ RI and then phosphorylating the SMA and MAD homologs SMAD2 and SMAD3, which associate with SMAD4 and together translocate to the nucleus for transcription of genes. All of this is inhibited by SMAD7 [53]. Interestingly, the TGF- $\beta$-R-initiated SMAD pathway was shown to target CEACAM5 (and CEACAM6) genes leading to CEA secretion as a mechanism for proliferation in gastric cancer cells [54]. It will be interesting in the future to investigate whether a synergistic crosstalk between the CEA and TGF- $\beta$ signaling cascades in cancer cells exists.

In human head and neck squamous cell carcinoma cell lines, Freudlsperger et al. [53] could further demonstrate that TGF- $\beta$ signaling resulted in a sequential phosphorylation of the transforming growth factor-activated kinase-1 (TAK1), inhibitor of nuclear factor kappa-B kinase (IKK), inhibitor of kappa-B subunit alpha $(\mathrm{I} \kappa \mathrm{B} \alpha)$ and the v-rel avian reticuloendotheliosis viral oncogene homolog A (RelA); however, the crosstalk to CEA was not addressed in this study. Nor did this study address the consecutive activation of TAK1/mitogen-activated protein kinase kinase (MEK)/protein kinase B (AKT)/NFKB and SMAD pathways upon TGF- $\beta$ stimulation as Gingery et al. [55] did in osteoclasts.

In human cancers, mutations in the TGF- $\beta$ pathways (e.g., TGF- $\beta$-RII or SMAD4) are frequently observed [56]. A recent study has indicated that, although most tested colorectal cancer cells displayed an inactivated TGF- $\beta$ signaling pathway, they actively secreted TGF- $\beta$ acting on stromal cells and were thus driving metastasis [57]. In other cancer cell types, TGF- $\beta$ signaling is intact, but aberrant $\mathrm{NF} \kappa \mathrm{B}$ activation and $\mathrm{NF \kappa B} / \mathrm{RelA}$ stimulate proliferation. In this respect, it should be emphasized that NFKB is constitutively activated in a number of hematologic and solid tumors and is one of the major transcription factors associated with cancer progression, inhibition of apoptosis, limitless replicative potential, tissue invasion and metastasis [58].

The TGF- $\beta-R$ and NFkB pathways are connected via the TAK-1, which (independently, but parallel to SMAD activation) by phosphorylating IKK can directly stimulate the nuclear factor- $\mathrm{KB}(\mathrm{NF \kappa B})$ pathway [55]. It is tempting to speculate that CEA may induce similar signals by interacting with TGF- $\beta-R$ [26]. TAK1 was expressed in head and neck cancers, where nuclear activation of RelA of the NFkB family also took place. TGF- $\beta$ induced sequential phosphorylation of several targets including TAK1, IKK, ІкB $\alpha$ and RelA; additionally, TAK1 again enhanced TGF- $\beta$ induced $\mathrm{NF \kappa B}$ activation [53]. In human neutrophils, a constitutive association of TAK1 and inhibitor of kappa-B (ІкB) was recently reported, indicating a close association of these pathways in inflammatory cells [59]. Neil et al. could show that the TAK1-binding protein 1 (TAB 1) forms complexes with IKB kinase $b(\mathrm{IKKb})$ resulting in stimulation of the TAK1:IKKb:RelA pathway. The authors concluded that this 
axis, including the NFKB elements, is pivotal in the oncogenic transformation of breast cancer [60]. The fact that $\mathrm{NF \kappa B}$ plays a critical role in both intrinsic and acquired resistance against endocrine therapy in human breast cancer cells may additionally complicate the situation [61].

\section{Conclusion}

Generally, the dog represents an optimal model organism to study cancer biology in a comparative setting, as many genes represent a great degree of homology to their human counterparts [62]. Even with respect to noncoding RNAs, the significance of similarities between human and dog has recently been acknowledged [63]. Furthermore, the intriguing amino acid homogeneity among human and canine CEAR, TGF- $\beta$ and TGF- $\beta$-R isoforms, NFkB and RelA are given in Table 1, indicating again an advantage of the dog patient in comparative oncology.

We propose that understanding of the crosstalk between CEA and TGF- $\beta$ signaling toward NFKB as a key cancer regulator, as well as understanding of the Treg and Breg action in tumor tissue, should be extended, possibly with prognostic value. The dog may be a relevant translational model to study these interactions, in line with the comparative oncology strategy [64]. In the future, novel drugs may target the Achilles heel of both obviously interconnected networks.

Acknowledgments The authors were supported by Project P23398-B11 of the Austrian Science Fund (FWF), Judit Fazekas by the Cell Communication in Health and Disease (CCHD) PhD Program W1205-B09 of the Austrian Science Fund (FWF). We would like to thank Mrs. Amelia Wein for proofreading the manuscript.

Conflict of interest The authors declare that they have no conflict of interest pertaining to the contents of this article.

Open Access This article is distributed under the terms of the Creative Commons Attribution License which permits any use, distribution, and reproduction in any medium, provided the original author(s) and the source are credited.

\section{References}

1. (The American Veterinary Medical Association) One health initiative task force. One health: a new professional imperative. https://www.avma.org/KB/Resources/Reports/Documents/onehealth_final.pdf. Accessed Sept 272013

2. Egenvall A, Bonnett BN, Ohagen P, Olson P, Hedhammar A, von Euler H (2005) Incidence of and survival after mammary tumors in a population of over 80,000 insured female dogs in Sweden from 1995 to 2002. Prev Vet Med 69:109-127. doi:10.1016/j. prevetmed.2005.01.014

3. Jemal A, Bray F, Center MM, Ferlay J, Ward E, Forman D (2011) Global cancer statistics. CA Cancer J Clin 61:69-90. doi: $10.3322 /$ caac. 20107
4. Richter SH, Garner JP, Auer C, Kunert J, Wurbel H (2010) Systematic variation improves reproducibility of animal experiments. Nat Methods 7:167-168. doi:10.1038/nmeth0310-167

5. Singer J, Weichselbaumer M, Stockner T et al (2012) Comparative oncology: ErbB-1 and ErbB-2 homologues in canine cancer are susceptible to cetuximab and trastuzumab targeting. Mol Immunol 50:200-209. doi:10.1016/j.molimm.2012.01.002

6. Singer J, Fazekas J, Wang W et al (2014) Generation of a canine anti-EGFR (ErbB-1) antibody for passive immunotherapy in dog cancer patients. Mol Cancer Ther 13:1777-1790. doi:10.1158/1535-7163.MCT-13-0288

7. Iwanicki-Caron I, Di Fiore F, Roque I et al (2008) Usefulness of the serum carcinoembryonic antigen kinetic for chemotherapy monitoring in patients with unresectable metastasis of colorectal cancer. J Clin Oncol 26:3681-3686. doi:10.1200/ jco.2007.15.0904

8. Bast RC, Ravdin P, Hayes DF et al (2001) 2000 Update of recommendations for the use of tumor markers in breast and colorectal cancer: clinical practice guidelines of the american society of clinical oncology*. J Clin Oncol 19:1865-1878

9. Ogoshi K, Miyaji M, Nakamura K, Kondoh Y, Makuuchi H, Tajima T (1998) Immunotherapy and combined assay of serum levels of carcinoembryonic antigen and acute-phase reactants. Cancer Immunol Immunother : CII 46:14-20

10. Zebhauser R, Kammerer R, Eisenried A, McLellan A, Moore T, Zimmermann W (2005) Identification of a novel group of evolutionarily conserved members within the rapidly diverging murine Cea family. Genomics 86:566-580. doi:10.1016/j. ygeno.2005.07.008

11. Kammerer R, Popp T, Hartle S, Singer BB, Zimmermann W (2007) Species-specific evolution of immune receptor tyrosine based activation motif-containing CEACAM1related immune receptors in the dog. BMC Evol Biol 7:196. doi:10.1186/1471-2148-7-196

12. Hostetter RB, Augustus LB, Mankarious R, Chi K, Fan D, Toth C, Thomas P, Jessup JM (1990) Carcinoembryonic antigen as a selective enhancer of colorectal cancer metastasis. J Natl Cancer Inst 82:380-385. doi:10.1093/jnci/82.5.380

13. Thomas SN, Zhu F, Schnaar RL, Alves CS, Konstantopoulos $\mathrm{K}$ (2008) Carcinoembryonic antigen and CD44 variant isoforms cooperate to mediate colon carcinoma cell adhesion to E- and L-selectin in shear flow. J Biol Chem 283:15647-15655. doi:10.1074/jbc.M800543200

14. Bajenova O, Chaika N, Tolkunova E, Davydov-Sinitsyn A, Gapon S, Thomas P, O'Brien S (2014) Carcinoembryonic antigen promotes colorectal cancer progression by targeting adherens junction complexes. Exp Cell Res 324:115-123. doi:10.1016/j.yexcr.2014.04.007

15. Triozzi PL, Aldrich W, Ponnazhagan S (2011) Inhibition and promotion of tumor growth with adeno-associated virus carcinoembryonic antigen vaccine and Toll-like receptor agonists. Cancer Gene Ther 18:850-858. doi:10.1038/cgt.2011.54

16. Witzens-Harig M, Hose D, Junger $S$ et al (2013) Tumor cells in multiple myeloma patients inhibit myeloma-reactive $\mathrm{T}$ cells through carcinoembryonic antigen-related cell adhesion molecule-6. Blood 121:4493-4503. doi:10.1182/ blood-2012-05-429415

17. Muturi HT, Dreesen JD, Nilewski E, Jastrow H, Giebel B, Ergun S, Singer BB (2013) Tumor and endothelial cell-derived microvesicles carry distinct CEACAMs and influence T-cell behavior. PLoS One 8:e74654. doi:10.1371/journal.pone.0074654

18. Muller MM, Singer BB, Klaile E, Obrink B, Lucka L (2005) Transmembrane CEACAM1 affects integrin-dependent signaling and regulates extracellular matrix protein-specific morphology and migration of endothelial cells. Blood 105:3925-3934. doi:10.1182/blood-2004-09-3618 
19. Vannucci L (2014) Stroma as an active player in the development of the tumor microenvironment. Cancer Microenviron. doi:10.1007/s12307-014-0150-x

20. Weichselbaumer M, Willmann M, Reifinger M et al (2011) Phylogenetic discordance of human and canine carcinoembryonic antigen (CEA, CEACAM) families, but striking identity of the CEA receptors will impact comparative oncology studies. PLoS Curr 3:RRN1223. doi:10.1371/currents.RRN1223

21. Bajenova OV, Zimmer R, Stolper E, Salisbury-Rowswell J, Nanji A, Thomas P (2001) Heterogeneous RNA-binding protein M4 is a receptor for carcinoembryonic antigen in Kupffer cells. J Biol Chem 276:31067-31073. doi:10.1074/jbc.M104093200

22. Laguinge L, Bajenova O, Bowden E, Sayyah J, Thomas P, Juhl H (2005) Surface expression and CEA binding of hnRNP M4 protein in HT29 colon cancer cells. Anticancer Res 25:23-31

23. Zhao HM, Zhang S, Gao F (2010) Expression of carcinoembryonic antigen receptor in digestive organs. Zhonghua Wei Chang Wai Ke Za Zhi 13:608-611

24. Thomas P, Forse RA, Bajenova O (2011) Carcinoembryonic antigen (CEA) and its receptor hnRNP $M$ are mediators of metastasis and the inflammatory response in the liver. Clin Exp Metastasis 28:923-932. doi:10.1007/s10585-011-9419-3

25. Palermo NY, Thomas P, Murphy RF, Lovas S (2012) Hexapeptide fragment of carcinoembryonic antigen which acts as an agonist of heterogeneous ribonucleoprotein M. J Pept Sci 18:252260. doi: $10.1002 / p s c .2393$

26. Li Y, Cao H, Jiao Z, Pakala SB, Sirigiri DN, Li W, Kumar R, Mishra L (2010) Carcinoembryonic antigen interacts with TGF- $\{$ beta $\}$ receptor and inhibits TGF- $\{$ beta $\}$ signaling in colorectal cancers. Cancer Res 70:8159-8168. doi:10.1158/0008-5472.CAN-10-1073

27. Hart PJ, Deep S, Taylor AB, Shu Z, Hinck CS, Hinck AP (2002) Crystal structure of the human TbetaR2 ectodomain-TGF-beta3 complex. Nat Struct Biol 9:203-208. doi:10.1038/nsb766

28. Wrana JL, Attisano L, Carcamo J, Zentella A, Doody J, Laiho M, Wang XF, Massague J (1992) TGF beta signals through a heteromeric protein kinase receptor complex. Cell 71:1003-1014. doi:10.1016/0092-8674(92)90395-S

29. Huang T, David L, Mendoza V et al (2011) TGF- $\beta$ signalling is mediated by two autonomously functioning T $\beta R I$ : T $\beta$ RII pairs. EMBO J 30:1263-1276. doi:10.1038/emboj.2011.54

30. Adeegbe DO, Nishikawa H (2013) Natural and induced T regulatory cells in cancer. Front Immunol 4:190. doi:10.3389/ fimmu.2013.00190

31. Carvalho MI, Pires I, Prada J, Queiroga FL (2014) A role for T-lymphocytes in human breast cancer and in canine mammary tumors. Biomed Res Int 2014:130894. doi:10.1155/2014/130894

32. O'Neill K, Guth A, Biller B, Elmslie R, Dow S (2009) Changes in regulatory $\mathrm{T}$ cells in dogs with cancer and associations with tumor type. J Vet Intern Med 23:875-881. doi:10.1111/j.1939-1676.2009.0333.x

33. Pinheiro D, Chang YM, Bryant $\mathrm{H}$ et al (2014) Dissecting the regulatory microenvironment of a large animal model of nonHodgkin lymphoma: evidence of a negative prognostic impact of FOXP3 $+\mathrm{T}$ cells in canine B cell lymphoma. PLoS One 9:e105027. doi:10.1371/journal.pone.0105027

34. Whiteside TL (2014) Regulatory T cell subsets in human cancer: are they regulating for or against tumor progression? Cancer Immunol Immunother: CII 63:67-72. doi:10.1007/ s00262-013-1490-y

35. Biragyn A, Lee-Chang C, Bodogai M (2014) Generation and identification of tumor-evoked regulatory B cells. Methods Mol Biol 1190:271-289. doi:10.1007/978-1-4939-1161-5_19

36. Lindner S, Dahlke K, Sontheimer K et al (2013) Interleukin 21-induced granzyme B-expressing B cells infiltrate tumors and regulate T cells. Cancer Res 73:2468-2479. doi:10.1158/00085472.CAN-12-3450
37. Olkhanud PB, Damdinsuren B, Bodogai M, Gress RE, Sen R, Wejksza K, Malchinkhuu E, Wersto RP, Biragyn A (2011) Tumorevoked regulatory $\mathrm{B}$ cells promote breast cancer metastasis by converting resting CD4(+) T cells to T-regulatory cells. Cancer Res 71:3505-3515. doi:10.1158/0008-5472.CAN-10-4316

38. Mele V, Muraro MG, Calabrese D et al (2014) Mesenchymal stromal cells induce epithelial-to-mesenchymal transition in human colorectal cancer cells through the expression of surfacebound TGF-beta. Int J Cancer 134:2583-2594. doi:10.1002/ ijc. 28598

39. Lee C, Jia Z, Rahmatpanah F, Zhang Q, Zi X, McClelland M, Mercola D (2014) Role of the adjacent stroma cells in prostate cancer development and progression: synergy between TGF-beta and IGF signaling. Biomed Res Int 2014:502093. doi: $10.1155 / 2014 / 502093$

40. Zhang J, Wang Y, Li D, Jing S (2014) Notch and TGF-beta/ Smad3 pathways are involved in the interaction between cancer cells and cancer-associated fibroblasts in papillary thyroid carcinoma. Tumour Biol 35:379-385. doi:10.1007/s13277-013-1053-Z

41. Gupta DK, Singh N, Sahu DK (2014) TGF-beta mediated crosstalk between malignant hepatocyte and tumor microenvironment in hepatocellular carcinoma. Cancer Growth Metastasis 7:1-8. doi:10.4137/CGM.S14205

42. Cufi S, Vazquez-Martin A, Oliveras-Ferraros C, Martin-Castillo B, Joven J, Menendez JA (2010) Metformin against TGFbeta-induced epithelial-to-mesenchymal transition (EMT): from cancer stem cells to aging-associated fibrosis. Cell Cycle 9:4461-4468

43. Dunning NL, Laversin SA, Miles AK, Rees RC (2011) Immunotherapy of prostate cancer: should we be targeting stem cells and EMT? Cancer Immunol Immunother: CII 60:1181-1193. doi:10.1007/s00262-011-1065-8

44. Singh A, Settleman J (2010) EMT, cancer stem cells and drug resistance: an emerging axis of evil in the war on cancer. Oncogene 29:4741-4751. doi:10.1038/onc.2010.215

45. Taylor MA, Sossey-Alaoui K, Thompson CL, Danielpour D, Schiemann WP (2013) TGF-beta upregulates miR-181a expression to promote breast cancer metastasis. J Clin Investig 123:150-163. doi:10.1172/JCI64946

46. Kim JH, Hur JH, Lee SM, Im KS, Kim NH, Sur JH (2012) Correlation of Foxp3 positive regulatory $\mathrm{T}$ cells with prognostic factors in canine mammary carcinomas. Vet J 193:222-227. doi:10.1016/j.tvj1.2011.10.022

47. Moo-Young TA, Larson JW, Belt BA, Tan MC, Hawkins WG, Eberlein TJ, Goedegebuure PS, Linehan DC (2009) Tumorderived TGF-beta mediates conversion of CD4 + Foxp3 + regulatory $\mathrm{T}$ cells in a murine model of pancreas cancer. J Immunother 32:12-21. doi:10.1097/CJI.0b013e318189f13c

48. Li Q, Li Q, Chen J et al (2013) Prevalence of Th17 and Treg cells in gastric cancer patients and its correlation with clinical parameters. Oncol Rep 30(3):1215-1222. doi:10.3892/or.2013.2570

49. Kammerer R, von Kleist S (1996) The carcinoembryonic antigen (CEA) modulates effector-target cell interaction by binding to activated lymphocytes. Int J Cancer 68:457-463. doi:10.1002/ (SICI) 1097-0215(19961115)68:4<457:AID-IJC10>3.0.CO;2-2

50. Chen L, Chen Z, Baker K et al (2012) The short isoform of the CEACAM1 receptor in intestinal $\mathrm{T}$ cells regulates mucosal immunity and homeostasis via Tfh cell induction. Immunity 37:930-946. doi:10.1016/j.immuni.2012.07.016

51. Oeckinghaus A, Hayden MS, Ghosh S (2011) Crosstalk in NF-kappaB signaling pathways. Nat Immunol 12:695-708. doi:10.1038/ni.2065

52. Pasparakis M, Luedde T, Schmidt-Supprian M (2006) Dissection of the NF-kappaB signalling cascade in transgenic and knockout mice. Cell Death Differ 13:861-872. doi:10.1038/ sj.cdd. 4401870 
53. Freudlsperger C, Bian Y, Contag Wise S, Burnett J, Coupar J, Yang X, Chen Z, Van Waes C (2013) TGF-beta and NFkappaB signal pathway cross-talk is mediated through TAK1 and SMAD7 in a subset of head and neck cancers. Oncogene 32:1549-1559. doi:10.1038/onc.2012.171

54. Han SU, Kwak TH, Her KH et al (2008) CEACAM5 and CEACAM6 are major target genes for Smad3-mediated TGF-beta signaling. Oncogene 27:675-683. doi:10.1038/sj.onc.1210686

55. Gingery A, Bradley EW, Pederson L, Ruan M, Horwood NJ, Oursler MJ (2008) TGF-beta coordinately activates TAK1/MEK/ AKT/NFkB and SMAD pathways to promote osteoclast survival. Exp Cell Res 314:2725-2738. doi:10.1016/j.yexcr.2008.06.006

56. Elliott RL, Blobe GC (2005) Role of transforming growth factor Beta in human cancer. J Clin Oncol 23:2078-2093. doi:10.1200/ JCO.2005.02.047

57. Calon A, Espinet E, Palomo-Ponce S et al (2012) Dependency of colorectal cancer on a TGF-beta-driven program in stromal cells for metastasis initiation. Cancer Cell 22:571-584. doi:10.1016/j. ccr.2012.08.013

58. Naugler WE, Karin M (2008) NF-kappaB and cancer-identifying targets and mechanisms. Curr Opin Genet Dev 18:19-26. doi:10.1016/j.gde.2008.01.020

59. Ear T, Fortin CF, Simard FA, McDonald PP (2010) Constitutive association of TGF-beta-activated kinase 1 with the IkappaB kinase complex in the nucleus and cytoplasm of human neutrophils and its impact on downstream processes. J Immunol 184:3897-3906. doi:10.4049/jimmunol.0902958

60. Neil JR, Schiemann WP (2008) Altered TAB 1: I kappaB kinase interaction promotes transforming growth factor beta-mediated nuclear factor-kappaB activation during breast cancer progression. Cancer Res 68:1462-1470. doi:10.1158/0008-5472. CAN-07-3094

61. Oida K, Matsuda A, Jung K et al (2014) Nuclear factor-kB plays a critical role in both intrinsic and acquired resistance against endocrine therapy in human breast cancer cells. Sci Rep 4:4057. doi: $10.1038 /$ srep04057

62. Lindblad-Toh K, Wade CM, Mikkelsen TS et al (2005) Genome sequence, comparative analysis and haplotype structure of the domestic dog. Nature 438:803-819. doi:10.1038/nature04338

63. Wagner S, Willenbrock S, Nolte I, Murua Escobar H (2013) Comparison of non-coding RNAs in human and canine cancer. Front Genet 4:46. doi:10.3389/fgene.2013.00046

64. Riccardo F, Aurisicchio L, Impellizeri JA, Cavallo F (2015) The importance of comparative oncology in translational medicine. Cancer Immunol Immunother: CII 64:137-148. doi:10.1007/ s00262-014-1645-5 